\title{
Imidazolium-based Ionic Liquids Impregnated in Silica and Alumina Supports for $\mathrm{CO}_{2}$ Capture
}

Bárbara Burlini Polesso ${ }^{a}$, Rafael Duczinski ${ }^{a}$, Franciele Longaray Bernard $^{b}$, Henrique Zucchetti Ferrari ${ }^{b}$, Murilo da Luz ${ }^{b}$, Felipe Dalla Vecchia ${ }^{a, b, c}$, Sonia Maria Cabral de Menezes ${ }^{d}$, Sandra Einlof $t^{a, b} *$ (1)

\author{
${ }^{a}$ Programa de Pós-Graduação em Engenharia e Tecnologia de Materiais, Pontifícia Universidade \\ Católica do Rio Grande do Sul (PUCRS), Porto Alegre, RS, Brasil \\ ${ }^{b}$ Escola Politécnica, Pontifícia Universidade Católica do Rio Grande do Sul (PUCRS), \\ Porto Alegre, RS, Brasil \\ 'Instituto de Petróleo e Recursos Naturais, Universidade Católica do Rio Grande do Sul (PUCRS), \\ Porto Alegre, RS, Brasil \\ ${ }^{d}$ Centro de Pesquisa e Desenvolvimento Leopoldo Américo Miguez de Mello (CENPES), Petrobrás, Ilha \\ do Fundão, RJ, Brasil
}

Received: December 06, 2018; Revised: June 26, 2019; Accepted: July 17, 2019

Ionic liquids (ILs) physical immobilization in solid materials is a key strategy for developing efficient and low cost $\mathrm{CO}_{2}$ capture processes. In this work, two porous commercial substrates with different characteristics (silica and alumina) were impregnated with ILs by physical wet method. Imidazolium based IL combined with $[\mathrm{Br}]^{-}$and $\left[\mathrm{Tf}_{2} \mathrm{~N}\right]^{-}$anions were used in impregnation process. $\mathrm{CO}_{2}$ sorption capacity and selectivity $\left(\mathrm{CO}_{2} / \mathrm{N}_{2}\right)$ of these materials were investigated. The best results regarding $\mathrm{CO}_{2} / \mathrm{N}_{2}$ selectivity and $\mathrm{CO}_{2}$ sorption were obtained with $\left[\mathrm{Tf}_{2} \mathrm{~N}\right]^{-}$anion. In relation to solid support, commercial alumina exhibited enhanced $\mathrm{CO}_{2}$ uptake and higher selective capacity $\left(\mathrm{CO}_{2} / \mathrm{N}_{2}\right)$ $(6.1( \pm 0.1))$. Combination of commercial alumina as support and $20 \mathrm{wt} \%$ of $\operatorname{mbmim}\left[\mathrm{Tf}_{2} \mathrm{~N}\right]$ resulted in higher $\mathrm{CO}_{2} / \mathrm{N}_{2}$ selectivity of $9.5 \pm 1.0$. In addition, this material also showed fast sorption kinetics when compared to pure IL besides reuse capacity.

Keywords: porous materials, ionic liquids, $\mathrm{CO}_{2}$ capture.

\section{Introduction}

One of the main challenges is the increase in atmospheric $\mathrm{CO}_{2}$ concentration ${ }^{1}$. According to measurements, the mean $\mathrm{CO}_{2}$ level value is the highest already registered till date ${ }^{1,2}$. This fact underscores the need of reducing $\mathrm{CO}_{2}$ emissions from industrial sources (industrial processes and fossil fuels use/production) which are one of the main players contributing to this scenario ${ }^{2-5}$. Current processes for $\mathrm{CO}_{2}$ capture are associated with high cost, energy penalty and chemical production limiting its use. The most well-known process involves aqueous amine solutions ${ }^{6,7}$. Despite being widespread this process presents operational drawbacks (high energy for regeneration stage, degradation byproducts, equipment corrosion) that discourage its use $\mathrm{e}^{5,8-13}$.

Ionic liquids (ILs) are a class of organic salts formed by combining organic cations and inorganic or organic anions resulting in compounds presenting melting temperature lower than $100^{\circ} \mathrm{C}^{14,15}$. ILs are candidates for replacing aqueous amine solution in $\mathrm{CO}_{2}$ capture processes ${ }^{15,16}$ due to their physico-chemical properties (like negligible vapor pressure) as well as $\mathrm{CO}_{2}$ sorption capacity ${ }^{1,17-20}$. Ionic liquids' properties depend on cation and anion size, shape and nature ${ }^{21,22}$. Side chain branched imidazolium cation is considered promising for $\mathrm{CO}_{2}$ capture since it imparts sponge-like characteristics ${ }^{23}$. Moreover, anion nature has a

*e-mail: einloft@pucrs.br great effect on gas solubility ${ }^{24}$. Fluorinated anions (such as $\left[\mathrm{Tf}_{2} \mathrm{~N}^{-}\right.$) present high $\mathrm{CO}_{2}$ affinity ${ }^{25,26}$. In spite of this, ionic liquids present disadvantages as high viscosity limiting mass transfer ${ }^{27}$. In order to overcome limitations related to ILs high viscosity, as poor $\mathrm{CO}_{2}$ dynamics separation, ILs impregnation in solid materials appears as a good platform ${ }^{28}$. Solid materials such as silica and alumina hold large specific surface area, pore volume, tunable pore size and good stability being interesting candidates for applications in separation processes $^{2,26,29-33}$. Besides these characteristics, some factors are fundamental to ensure these materials applicability, such as: fast kinetic, $\mathrm{CO}_{2}$ sorption capacity, $\mathrm{CO}_{2}$ selectivity, chemical and thermal stability ${ }^{1,34,35}$.

In this work we investigated anion and porous support effect on $\mathrm{CO}_{2}$ capture. Essential features to integrate this technique in large industrial systems such as $\mathrm{CO}_{2}$ sorption capacity, selectivity $\left(\mathrm{CO}_{2} / \mathrm{N}_{2}\right)$, recyclability, sorption kinetics and thermal stability were evaluated. Commercial silica and alumina were used as solid supports impregnated with the ionic liquids mbmim $[\mathrm{Br}]$ and mbmim $\left[\mathrm{Tf}_{2} \mathrm{~N}\right]$

\section{Experimental}

\subsection{Materials}

1-Methylmidazole (99\%, Sigma Aldrich), 1-Bromo-3methylbutane (96\%, Sigma Aldrich, Toluene (99.0\%, Merck), 
Ether (Neon), Lithium trifluoromethanesulfonylimidate (Alfa Aesar, 98.0\%), Magnesium Sulfate (Merck), Dichloromethane (Anhydrol), Commercial Silica (S) and Commercial Alumina (A) were used as received.

\subsection{Ionic Liquids synthesis}

The ionic liquid mbmim[Br] (1- (3-methylbutyl) -3methylimidazolium bromide) was synthesized as described by Andresova et al. ${ }^{36}$. Using this IL as starting material, anion exchange was carried out with lithium salt $\left(\operatorname{LiTf}_{2} \mathrm{~N}\right)$ addition $^{36}$, resulting in mbmim $\left[\mathrm{Tf}_{2} \mathrm{~N}\right]$ (1- (3-methylbutyl) -3-methylimidazolium bis- (trifluoromethanesulfonylimide). ILs syntheses were confirmed by proton nuclear magnetic resonance $\left({ }^{1} \mathrm{H}-\mathrm{NMR}\right)^{36}$, in a Varian spectrophotometer, VNMRS $300 \mathrm{MHz}$, using DMSO-d $\mathrm{d}_{6}$ as solvent and $5 \mathrm{~mm}$ diameter glass tubes. mbmim[Br]: ${ }^{1} \mathrm{H}-\mathrm{RMN}(300 \mathrm{MHz}$, DMSO-d $\left.{ }_{6}, 25^{\circ} \mathrm{C}\right), \delta(\mathrm{ppm}) 10.28(\mathrm{~m}, 1 \mathrm{H}), 7.79(\mathrm{t}, 1 \mathrm{H}), 7.61$ $(\mathrm{t}, 1 \mathrm{H}), 4.39-3.96(\mathrm{~m}, 4 \mathrm{H}), 1.87-1.69(\mathrm{~m}, 4 \mathrm{H}), 1.59(\mathrm{~m}, 1 \mathrm{H})$, $1.13(\mathrm{~m}, 2 \mathrm{H}), 0.85$ (t, 3H). mbmim[Tff $\mathbf{N}]:{ }^{1} \mathrm{H}-\mathrm{RMN}(300$ $\left.\mathrm{MHz}, \mathrm{DMSO}-\mathrm{d}_{6}, 25^{\circ} \mathrm{C}\right) \delta(\mathrm{ppm}) 9.13(\mathrm{~s}, 1 \mathrm{H}), 7.79(\mathrm{~d}, 1 \mathrm{H})$, $7.70(\mathrm{~d}, 1 \mathrm{H}), 4.24(\mathrm{t}, 2 \mathrm{H}), 3.85(\mathrm{~s}, 3 \mathrm{H}), 1.69(\mathrm{~m}, 2 \mathrm{H}), 1.51$ $(\mathrm{m}, 1 \mathrm{H}), 0.92(\mathrm{~d}, 6 \mathrm{H})$. ILs structures are depicted in Fig. 1.

\subsection{Physical wet method immobilization}

Ionic liquids immobilization in commercial porous substrates (silica $\mathrm{S}$ and alumina $\mathrm{A}$ ) was performed by wet impregnation. In this technique the IL (mbmim[Br] or $\left.\operatorname{mbmim}\left[\mathrm{Tf}_{2} \mathrm{~N}\right]\right)$ in concentrations of 10 to $30 \% \mathrm{wt}$ is dissolved in dichloromethane; the contact with the support is effected manually with a pistil ${ }^{37}$. Samples were named as $\mathrm{X}$-mbmim[Y]-Z, where $\mathrm{X}$ indicates the solid support (silica $\mathrm{S}$ or alumina $\mathrm{A}$ ), $\mathrm{Y}$ the anion and $\mathrm{Z}$ the immobilized IL concentration. For example, S-mbmim[Tf $\left.{ }_{2} \mathrm{~N}\right]-10$ means silica support, $\mathrm{Tf}_{2} \mathrm{~N}$ anion and $10 \%$ wt of IL.

\section{$2.4 \mathrm{CO}_{2}$ sorption and sorption kinetics assays}

Pure and immobilized porous substrates sorption tests were performed statically through the cell-based pressure decay technique similar to that developed by Koros and Paul ${ }^{38}$. Tests were performed in triplicate at $45^{\circ} \mathrm{C}$ of temperature and $0.4 \mathrm{MPa}$ (equilibrium pressure). $\mathrm{CO}_{2}$ solubility procedure, tests and calculation, was performed as presented in our previously published works ${ }^{2,39}$. Solid and liquid sorption kinetic was evaluated by controlling $\mathrm{CO}_{2}$ sorption until saturation amount over time. Recycle tests were performed by repeating sorption/desorption cycles five times at 0.4 MPa with desorption after each cycle by sample heating in an oven at $65^{\circ} \mathrm{C}$. Kinetic tests and solubility calculations for ionic liquids were performed just as in the case of solids, but with constant stirring of $800 \mathrm{rpm}^{40}$.

\section{$2.5 \mathrm{CO}_{2} / \mathrm{N}_{2}$ separation - Selectivity tests}

Procedure for selectivity determination is well described in literature ${ }^{2,41}$. Tests were performed using a primary standard gaseous mixture with $\mathrm{CO}_{2}$ content of $15.89 \%$ and $\mathrm{N}_{2}$ balance. Experiments were carried out at equilibrium pressure of 2.3 $\mathrm{MPa}$ and temperature of $45^{\circ} \mathrm{C}$. $\mathrm{CO}_{2}$ separation efficiency was calculated by equation 1 , where Yi stands for molar fractions in the gas phase and $\mathrm{Xi}$ in the sorbed phase.

$$
S=\frac{X C O 2 / Y C O 2}{X N 2 / Y N 2}
$$

\subsection{Sample characterization}

Materials structures were identified by FTIR. FTIR spectra were recorded on a PerkinElmer Spectrum 100 spectrometer in UATR mode. Samples morphology was evaluated by Field Emission Scanning Electron Microscopy (FESEM) and performed on a FEI Inspect F50 equipment in secondary electron mode. Samples thermal stability and immobilized IL content were evaluated by TGA/DTG (TA Instruments SDT-Q600), under nitrogen inert atmosphere from 25 to $800^{\circ} \mathrm{C}$ and heating rate of $20^{\circ} \mathrm{C} / \mathrm{min}$. Samples porous nature was investigated by $\mathrm{N}_{2}$ adsorption/desorption technique and the specific surface area was calculated using the Brunauer - Emmett - Teller (BET) method. Nitrogen adsorption-desorption isotherm was obtained using NOVA 4200 High Speed at liquid nitrogen temperature. Bulk density was obtained by measuring in a vessel, dispersed powder volume and weight, under gravity influence. Skeleton density was determined by helium pycnometry (Ultrafoam TM $1200 \mathrm{e}$, Quantachrome Instruments). Porosity (\%) was theoretically
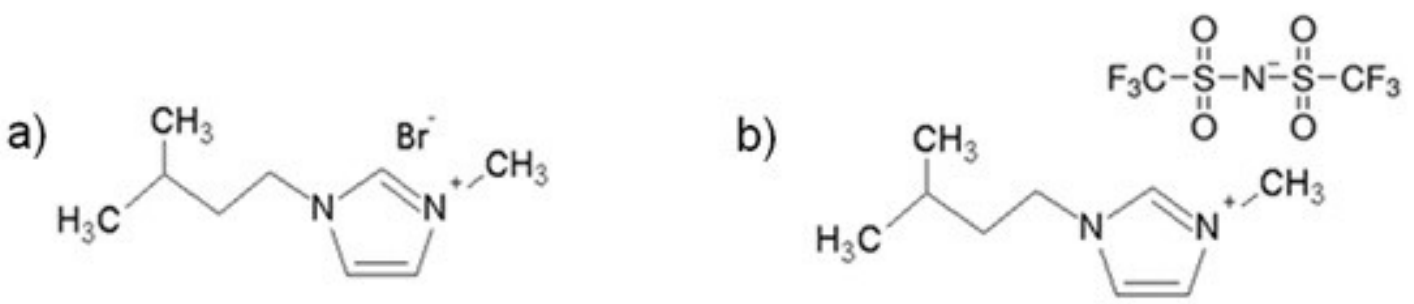

Figure 1. ILs structure: a) $\operatorname{mbmim}[\mathrm{Br}]$ b) $\operatorname{mbmim}\left[\mathrm{Tf}_{2} \mathrm{~N}\right]$. 
calculated using density and skeletal density results according to literature procedure ${ }^{42}$. IL samples content was determined by TGA in the range of 150 to $800^{\circ} \mathrm{C}$ using equation 2 . The weight loss of sample $\mathrm{S}(3.4 \%)$ and sample $\mathrm{A}(17.6 \%)$ without IL loading was used as control and subtracted from obtained value from equation 2 . For silica the observed weight loss up to $150^{\circ} \mathrm{C}$ corresponds to water loss. On the other hand, for alumina, besides weight loss related to moisture, there is also a weight loss corresponding to bohemite percentage and crystallites size $\mathrm{A}^{43}$.

$$
I L(\%)=\frac{W_{150}-W_{800}}{W_{150}} X 100
$$

Where $\mathrm{W}_{150}$ and $\mathrm{W}_{800}$ are weight $(\mathrm{g})$ at $150^{\circ} \mathrm{C}$ and $800^{\circ} \mathrm{C}$, respectively.

\section{Results and Discussion}

FTIR spectra of solid supports ( $\mathrm{S}$ and $\mathrm{A}$ ) as well as solid supports impregnated with ILs are shown in Fig. 2. Immobilized samples with different IL content presented similar behavior, so samples with $30 \%$ of ILs mbmim $[\mathrm{Br}]$ and $\operatorname{mbmim}\left[\mathrm{Tf}_{2} \mathrm{~N}\right]$ are used to illustrate the immobilization in silica support (S) and $\mathrm{mbmim}\left[\mathrm{Tf}_{2} \mathrm{~N}\right]$ to illustrate IL immobilization in alumina sample (A). In sample $\mathrm{S}$ (Fig. 2a) spectrum characteristic silica bands are observed ${ }^{2,44}$ : at $3352 \mathrm{~cm}^{-1}, 1635 \mathrm{~cm}^{-1}$ (hydroxyl), $1066 \mathrm{~cm}^{-1}$ (condensed silica Si-O-Si) and from $968 \mathrm{~cm}^{-1}$ to $798 \mathrm{~cm}^{-1}$ (Si-OH). With ILs immobilization (Fig. 2a) one can observe the appearance of imidazolium cation characteristic bands at ${ }^{45}: 2973 \mathrm{~cm}^{-1}\left(\mathrm{C}-\mathrm{H}\right.$ of $\left.\mathrm{CH}_{2}\right), 1633-1625 \mathrm{~cm}^{-1}(\mathrm{C}=\mathrm{N}$ aromatic), $1571-1471 \mathrm{~cm}^{-1}\left(\mathrm{C}=\mathrm{C}\right.$ aromatic), $1349 \mathrm{~cm}^{-1}(\mathrm{C}-\mathrm{N}$ aromatic), $1192 \mathrm{~cm}^{-1}$ (C-N aliphatic) and for $\left[\mathrm{Tf}_{2} \mathrm{~N}\right]$ anion $\mathrm{at}^{45}$ : $1054 \mathrm{~cm}^{-1}$ (N-S), $792 \mathrm{~cm}^{-1}$ (C-S), 741-657 $\mathrm{cm}^{-1}$ (C-F); and $[\mathrm{Br}]^{46}: 655 \mathrm{~cm}^{-1}(\mathrm{C}-\mathrm{Br})$. Sample A FTIR spectrum (Fig. 2b) evidenced characteristics bands at ${ }^{47,48}: 660 \mathrm{~cm}^{-1}$ (aluminum in oxide octahedral coordination), from 890 to $734 \mathrm{~cm}^{-1}$ (tetracoordinated aluminum). The band at 1060 $\mathrm{cm}^{-1}$ corresponds to Al- $\mathrm{OH}^{48}$. The bands at $1639 \mathrm{~cm}^{-1}$ and $3200 \mathrm{~cm}^{-1}$ correspond to angular and axial deformation of hydroxyls group, respectively ${ }^{47,48}$. The band at $1395 \mathrm{~cm}^{-1}$ is attributed to nitrate $\left(\mathrm{NO}_{3}^{-}\right)$and at $3089 \mathrm{~cm}^{-1}$ to alkyl groups $\left(-\mathrm{CH}_{2} /-\mathrm{CH}_{3}\right)$ probably from fabrication process ${ }^{47,48}$. With IL mbmim [Tf $\left.{ }_{2} \mathrm{~N}\right]$ immobilized in sample A (Fig. 2b) one can observe the appearance of imidazolium characteristic bands a ${ }^{45}: 2966 \mathrm{~cm}^{-1}\left(\mathrm{C}-\mathrm{H}\right.$ of $\left.\mathrm{CH}_{2}\right), 2878 \mathrm{~cm}^{-1}\left(\mathrm{C}-\mathrm{H}_{\text {of CH}}\right)$, $1571-1469 \mathrm{~cm}^{-1}$ ( $\mathrm{C}=\mathrm{C}$ aromatic), $1348 \mathrm{~cm}^{-1}$ (C-N aromatic), $1186-1135 \mathrm{~cm}^{-1}$ (C-N aliphatic) and for $\left[\mathrm{Tf}_{2} \mathrm{~N}\right]$ anion at ${ }^{45}$ : $1056 \mathrm{~cm}^{-1}$ (N-S), $876 \mathrm{~cm}^{-1}$ (N-S), $731 \mathrm{~cm}^{-1}$ (C-F).

Fig. 3 presents FESEM images for samples $\mathrm{S}$ and $\mathrm{A}$ as well as samples S-mbmim[Tf $\mathrm{N}]-30$ and A-mbmim[Tf $\mathrm{N}]-30$. Comparing sample $\mathrm{S}$ micrograph (Fig. 3, a) with sample S-mbmim[Tf $\left.{ }_{2} \mathrm{~N}\right]-30$ (Fig. 3, b) one can observe an increase in particle size with IL immobilization (from $\sim 25 \mu \mathrm{m}$ to $\sim 120 \mu \mathrm{m}$ ). For sample A-mbmim[Tf $\left.{ }_{2} \mathrm{~N}\right]-30$ (Fig. 3, d) an
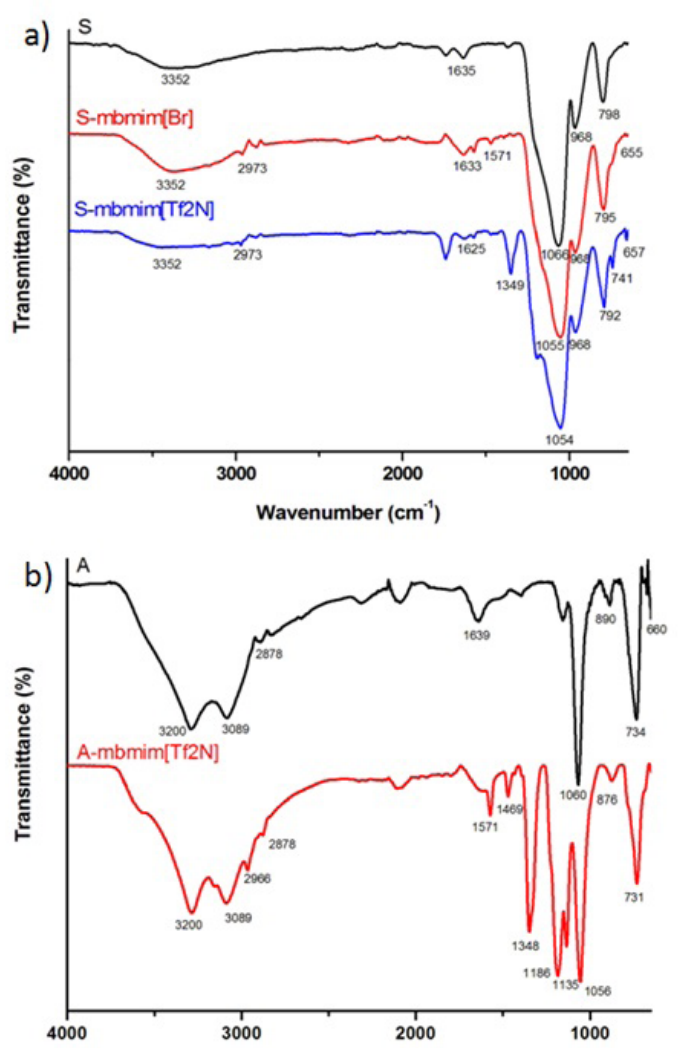

Figure 2. FTIR for samples: a) S, S-mbmim[Br]-30, S-mbmim[Tf $2 \mathrm{~N}]-30$; b) A and and A- mbmim[ $\left[\mathrm{Tf}_{2} \mathrm{~N}\right]-30$.

increase in particle size also was observed (from $\sim 24 \mu \mathrm{m}$ to $\sim 36 \mu \mathrm{m}$ ) when compared to sample A (Fig. 3, c). Particle size increases under IL immobilization. This behavior is probably related to particle agglomeration for both samples.

Table 1 shows the amount of immobilized IL in supports $\mathrm{S}$ and A determined by TGA. The actual percentage values obtained for both supports ( $\mathrm{S}$ and $\mathrm{A}$ ) were close to the theoretical one evidencing process efficiency.

$\mathrm{N}_{2}$ adsorption/desorption isotherm tests at $77 \mathrm{~K}$ were performed for all samples (Figure 4). Typical type IV curves with $\mathrm{H} 3$ hysteresis loop according to IUPAC classification were observed in all cases (Figure $4 \mathrm{~A})^{49-51}$ except for sample A-mbmim $\left[\mathrm{Tf}_{2} \mathrm{~N}\right]-30$ (Figure 4B). Sample A-mbim[ $\left.\mathrm{Tf}_{2} \mathrm{~N}\right]-30$ presented a isotherm characteristic of non-porous materials (type III). This behavior is possibly due to the amount of immobilized IL (30\%) resulting in pore saturation altering its textural properties ${ }^{51-53}$ (see Table 2).

Table 2 summarizes density and textural properties of all samples studied in this work. It is possible to observe that regardless the anion or the support, porosity, specific surface area, pore volume and pores radius were reduced with ILs immobilization. We can also highlight that the higher the ILs content the lower these values were probably due to pore filling. These data corroborates several studies reporting 

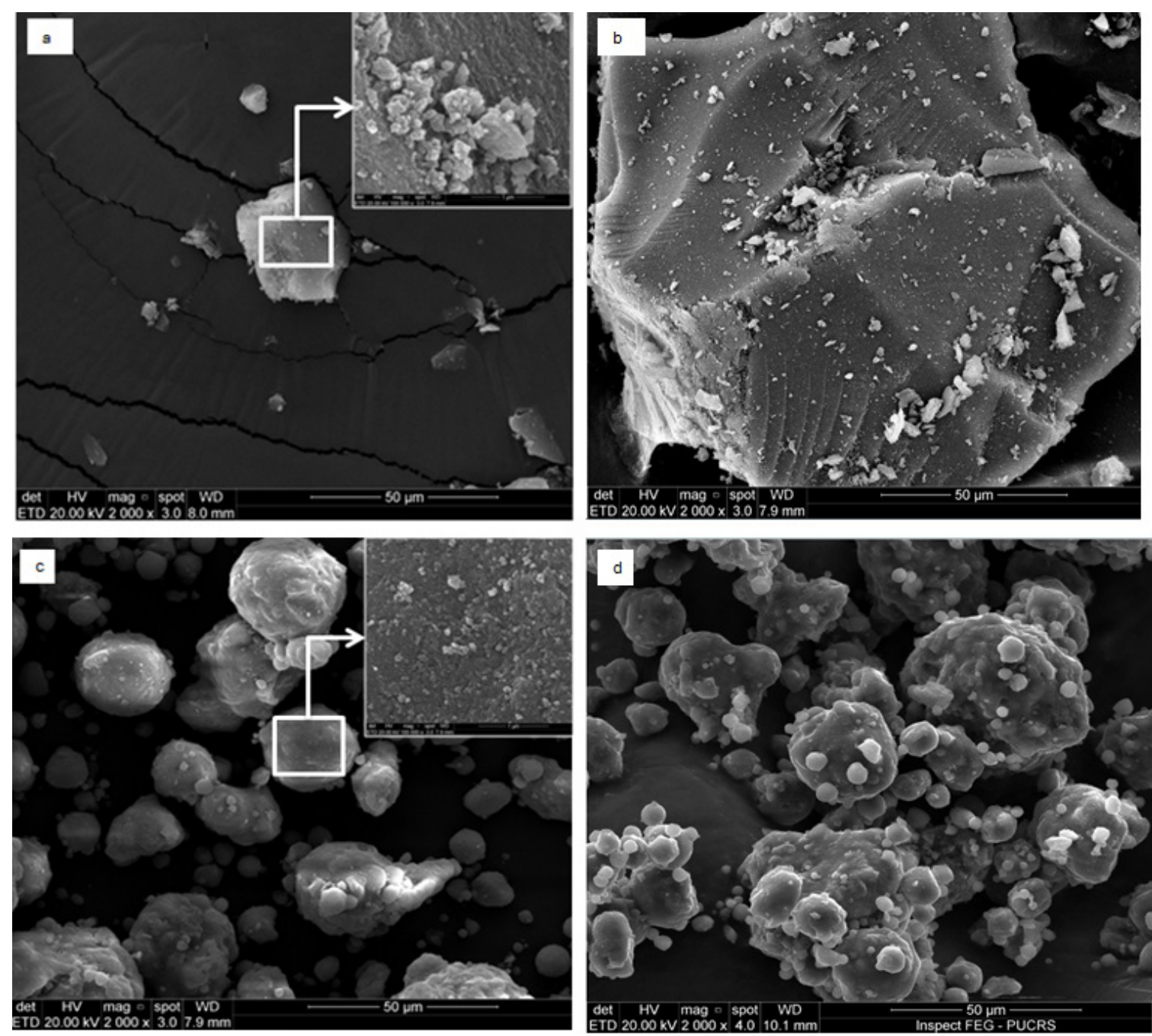

Figure 3. FESEM for samples: (a) $\mathrm{S}$; (b) $\mathrm{S}-\operatorname{mbmim}\left[\mathrm{Tf}_{2} \mathrm{~N}\right]-30$; (c) A; (d) A-mbmim[Tf $\left.2 \mathrm{~N}\right]-30$.
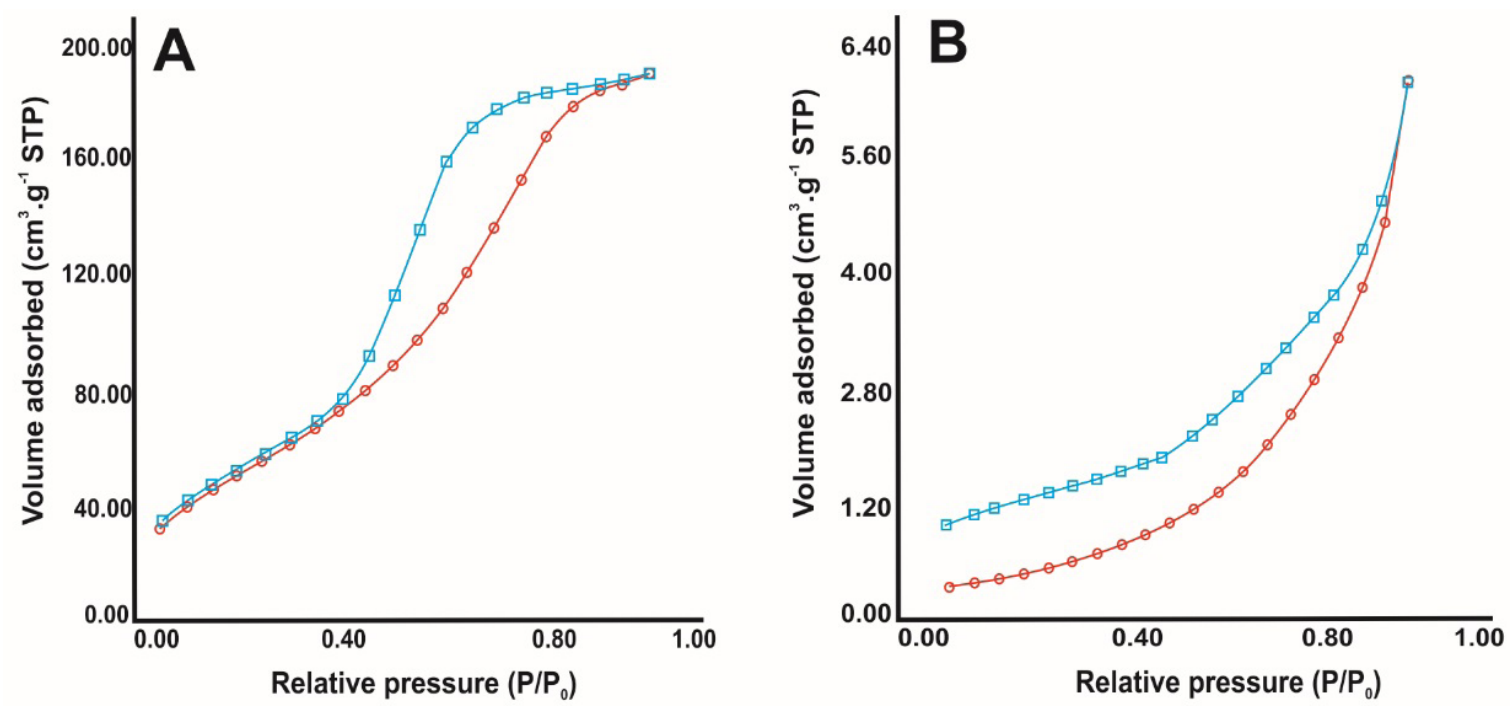

Figure 4. $\mathrm{N}_{2}$ isotherms of adsorption ( $\left(\right.$ ) and desorption ( $\square$ ): (A) A-mbmim[Tf $\left.{ }_{2} \mathrm{~N}\right]-20$; (B) A-mbmim[Tf $\left.{ }_{2} \mathrm{~N}\right]-30$. 
Table 1. Amount (\%) of immobilized IL in supports $\mathrm{S}$ and $\mathrm{A}$ determined by TGA.

\begin{tabular}{|c|c|}
\hline Sample & $\%$ IL \\
\hline S & - \\
\hline $\mathrm{S}-\mathrm{mbmim}[\mathrm{Br}]-10$ & $8.2( \pm 1.9)$ \\
\hline $\mathrm{S}-\mathrm{mbmim}[\mathrm{Br}]-20$ & $19.8( \pm 0.5)$ \\
\hline $\mathrm{S}-\mathrm{mbmim}[\mathrm{Br}]-30$ & $28.2( \pm 1.5)$ \\
\hline $\mathrm{S}-\operatorname{mbmim}\left[\mathrm{Tf}_{2} \mathrm{~N}\right]-10$ & $8.7( \pm 0.4)$ \\
\hline $\mathrm{S}-\mathrm{mbmim}\left[\mathrm{Tf}_{2} \mathrm{~N}\right]-20$ & $19.4( \pm 0.7)$ \\
\hline $\mathrm{S}-\mathrm{mbmim}\left[\mathrm{Tf}_{2} \mathrm{~N}\right]-30$ & $27.7( \pm 2.0)$ \\
\hline A & - \\
\hline A-mbmim $\left[\mathrm{Tf}_{2} \mathrm{~N}\right]-10$ & $8.1( \pm 1.0)$ \\
\hline A-mbmim $\left[\mathrm{Tf}_{2} \mathrm{~N}\right]-20$ & $18.2( \pm 0.8)$ \\
\hline A-mbmim $\left[\mathrm{Tf}_{2} \mathrm{~N}\right]-30$ & $26.6( \pm 0.4)$ \\
\hline
\end{tabular}

textural properties decrease after organic loading ${ }^{2,49-51}$ and also confirm that the relationship between bulk density and porosity is inversely proportional ${ }^{54}$.

\subsection{Influence of anion on $\mathrm{CO}_{2}$ sorption capacity}

Fig. 5 presents sorption values at $45^{\circ} \mathrm{C}$ of temperature and $0.4 \mathrm{MPa}$ of pressure for sample $\mathrm{S}$ and the ILs mbmim $[\mathrm{Br}]$ ] and $\operatorname{mbmim}\left[\mathrm{Tf}_{2} \mathrm{~N}\right]^{-}$, with different IL content, immobilized on sample $\mathrm{S}$. It can be seen that sample $\mathrm{S}$ presents the highest $\mathrm{CO}_{2}$ sorption capacity $\left(81.7( \pm 2.2) \mathrm{mg} \mathrm{CO}_{2} / \mathrm{g}\right)$ when compared to immobilized samples. This behavior is possibly associated with its high specific surface area $\left(487 \mathrm{~m}^{2} / \mathrm{g}\right)$. Polar groups
(Si-OH) on sample $\mathrm{S}$ surface also can improve $\mathrm{CO}_{2}$ sorption due to affinity with $\mathrm{CO}_{2}^{55}$. Regarding immobilized ILs a tendency in $\mathrm{CO}_{2}$ sorption capacity reduction with IL content increase was observed for both anions (S-mbmim $[\mathrm{Br}]-1071.7$ ( \pm 2.6) $\mathrm{mg} \mathrm{CO} / \mathrm{g} ; \mathrm{S}-\mathrm{mbmim}[\mathrm{Br}]-2054.8( \pm 1.0) \mathrm{mg} \mathrm{CO} / \mathrm{g}$; S-mbmim[Br]-30 55.1 ( \pm 1.3$) \mathrm{mg} \mathrm{CO}_{2} / \mathrm{g} ; \mathrm{S}-\mathrm{mbmim}\left[\mathrm{Tf}_{2} \mathrm{~N}\right]-10$ $56.0( \pm 0.7) \mathrm{mg} \mathrm{CO}_{2} / \mathrm{g} ; \mathrm{S}-\mathrm{mbmim}\left[\mathrm{Tf}_{2} \mathrm{~N}\right]-2055.8( \pm 1.0) \mathrm{mg}$ $\left.\mathrm{CO}_{2} / \mathrm{g}\right)$; S-mbmim[Tf $\left.\left.{ }_{2} \mathrm{~N}\right]-3045.2( \pm 2.3) \mathrm{mg} \mathrm{CO}_{2} / \mathrm{g}\right)$. This behavior is probably related to specific surface area and porosity reduction with IL immobilization (see Table 2). From results, one can infer that IL content and anion type has a secondary influence on sorption values. On the other hand, specific surface area is the main factor influencing $\mathrm{CO}_{2}$ sorption capacity. Higher sorption capacity was observed for sample S-mbmim [Br]-10 (71.7 ( \pm 2.6$) \mathrm{mg} \mathrm{CO}_{2} / \mathrm{g}$; $\mathrm{S}=441$ $\mathrm{m}^{2} / \mathrm{g}$ ) when compared to other samples containing IL with less important specific surface area values. Similar behavior was described by Kim et al. ${ }^{56}$. Results obtained in this work for silica samples/immobilized ILs were similar or higher than those reported in literature under the same pressure and temperature conditions ( $\sim 55 \mathrm{mg} \mathrm{CO}_{2} / \mathrm{g}$ ) for $10 \%$ amine (PEI and PEHA) immobilized on mesoporous silica ${ }^{57}$.

$\mathrm{CO}_{2} / \mathrm{N}_{2}$ selectivity for sample $\mathrm{S}$ as well as for sample $\mathrm{S}$ immobilized with ILs is depicted in Fig. 6. As seen, ILs immobilization improves silica samples selectivity. This behavior is probably related to imidazolium ring polarity ${ }^{58,59}$ and IL content ${ }^{60}$. Yet, ionic liquids have more affinity for $\mathrm{CO}_{2}$ when compared to other gases such as $\mathrm{CH}_{4}$ and $\mathrm{N}_{2}{ }^{61}$. The best result regarding selectivity was observed for anion $\left[\mathrm{Tf}_{2} \mathrm{~N}\right]$ and sample S-mbmim[Tf $\left.\mathrm{T}_{2} \mathrm{~N}\right]-30$ of $(7.9( \pm 0.2))$. This result is in accordance with literature which describes $\left[\mathrm{Tf}_{2} \mathrm{~N}\right]$ having high $\mathrm{CO}_{2}$ selectivity in gas mixtures when compared to other anions ${ }^{57}$. The best sorption capacity was obtained for sample $\mathrm{S}$, but the higher separation efficiency $\left(\mathrm{CO}_{2} / \mathrm{N}_{2}\right)$ was obtained by mbmim[Tf $\mathrm{Tf}_{2} \mathrm{~N}-30$ sample. This parameter has a direct impact on product purity degree, playing an important role in sorbent choice ${ }^{35}$. The presence

Table 2. Density and pore characteristics of all samples (S and A with and without IL immobilization).

\begin{tabular}{|c|c|c|c|c|c|c|}
\hline \multirow[b]{2}{*}{$\mathrm{S}$} & \multicolumn{2}{|c|}{$\begin{array}{c}\text { Densities }\left(\mathrm{g} / \mathrm{cm}^{3}\right) \\
\text { Bulk } \\
\text { Skeleton }\end{array}$} & \multirow{2}{*}{$\begin{array}{c}\begin{array}{c}\text { Porosity } \\
(\%)\end{array} \\
80.80\end{array}$} & \multirow{2}{*}{$\begin{array}{c}\begin{array}{c}\mathrm{BET} \\
\left(\mathrm{m}^{2} / \mathrm{g}\right)\end{array} \\
487\end{array}$} & \multirow{2}{*}{$\begin{array}{c}\text { Pore volume }\left(\mathrm{cm}^{3}\right) \\
0.75\end{array}$} & \multirow{2}{*}{$\begin{array}{c}\begin{array}{c}\text { Pore } \\
\text { Radius } \\
(\mathrm{nm})\end{array} \\
2.69\end{array}$} \\
\hline & 0.4428 & 2.306 & & & & \\
\hline $\mathrm{S}-\mathrm{mbmim}[\mathrm{Br}]-10$ & 0.5908 & 2.516 & 76.52 & 441 & 0.56 & 2.38 \\
\hline $\mathrm{S}-\mathrm{mbmim}[\mathrm{Br}]-20$ & 0.6166 & 2.219 & 72.21 & 367 & 0.45 & 2.10 \\
\hline $\mathrm{S}-\mathrm{mbmim}[\mathrm{Br}]-30$ & 0.6386 & 2.254 & 71.67 & 315 & 0.43 & 1.87 \\
\hline $\mathrm{S}-\mathrm{mbmim}\left[\mathrm{Tf}_{2} \mathrm{~N}\right]-10$ & 0.5926 & 3.071 & 80.70 & 381 & 0.54 & 2.38 \\
\hline $\mathrm{S}-\operatorname{mbmim}\left[\mathrm{Tf}_{2} \mathrm{~N}\right]-20$ & 0.6088 & 2.734 & 77.73 & 307 & 0.43 & 2.10 \\
\hline $\mathrm{S}-\operatorname{mbmim}\left[\mathrm{Tf}_{2} \mathrm{~N}\right]-30$ & 0.6578 & 2.901 & 77.33 & 291 & 0.41 & 2.38 \\
\hline A & 0.7434 & 3.366 & 77.91 & 196 & 0.26 & 2.12 \\
\hline $\mathrm{A}-\operatorname{mbmim}\left[\mathrm{Tf}_{2} \mathrm{~N}\right]-10$ & 0.8566 & 3.454 & 75.19 & 128 & 0.20 & 1.88 \\
\hline $\mathrm{A}-\mathrm{mbmim}\left[\mathrm{Tf}_{2} \mathrm{~N}\right]-20$ & 0.9044 & 2.562 & 64.70 & 73 & 0.12 & 2.75 \\
\hline A-mbmim $\left[\mathrm{Tf}_{2} \mathrm{~N}\right]-30$ & - & - & - & 7 & - & - \\
\hline
\end{tabular}




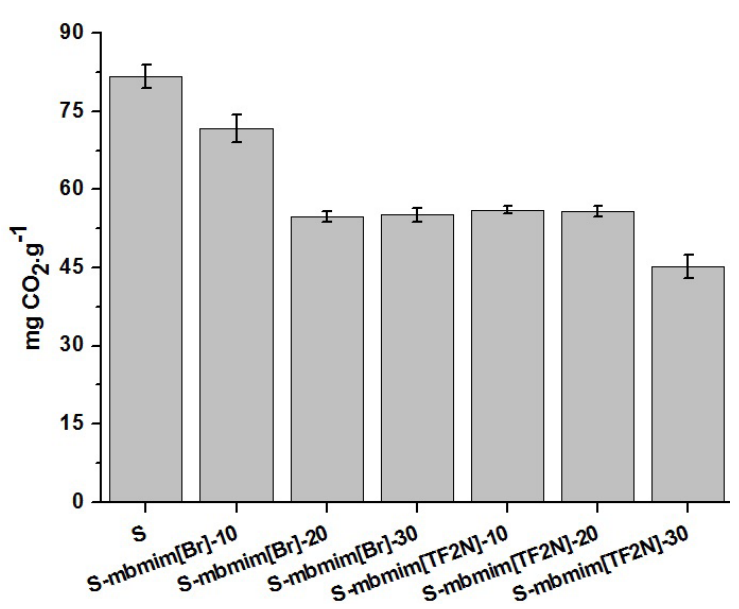

Figure 5. $\mathrm{CO}_{2}$ sorption capacity at $0.4 \mathrm{MPa}$ and $45^{\circ} \mathrm{C}$.

of $\left[\mathrm{Tf}_{2} \mathrm{~N}\right]$ anion results in the best material for $\mathrm{CO}_{2}$ capture. In the next section support performance evaluation will be described using mbmim $\left[\mathrm{Tf}_{2} \mathrm{~N}\right]$ as IL.

\subsection{Solid support role in $\mathrm{CO}_{2}$ sorption capacity and $\mathrm{CO}_{2} / \mathrm{N}_{2}$ selectivity}

Table 3 presents the results obtained for $\mathrm{CO}_{2}$ sorption and $\mathrm{CO}_{2} / \mathrm{N}_{2}$ selectivity for sample $A$ and sample $A$ immobilized with the IL mbmim $\left[\mathrm{TF}_{2} \mathrm{~N}\right]$ in different content in comparison with sample $\mathrm{S}$ and sample $\mathrm{S}$ with the IL $\operatorname{mbmim}\left[\mathrm{TF}_{2} \mathrm{~N}\right]$ in different content as well.

Analyzing the supports sorption capacity one can notice that sample A has lower sorption capacity $(61.1( \pm 1.2) \mathrm{mg}$ $\left.\mathrm{CO}_{2} / \mathrm{g}\right)$ once compared to sample $\mathrm{S}(81.7( \pm 2.2))$. This behavior is related to sample $\mathrm{S}$ specific surface area being twice as large as sample $\mathrm{A}$ (Table 2). Unlike $\mathrm{CO}_{2}$ sorption, selectivity $\left(\mathrm{CO}_{2} / \mathrm{N}_{2}\right)$ of sample $A$ is higher when compared to sample $\mathrm{S}$. This behavior is attributed to metal presence in sample A improving support/ $\mathrm{CO}_{2}$ affinity ${ }^{1,58,59,62,63}$. Comparing $\mathrm{CO}_{2}$ sorption capacity of IL immobilized samples one can observe a reduction in $\mathrm{CO}_{2}$ sorption values for all samples. This behavior is related to the decrease in textural properties (see Table 2), except for sample A-mbmim[ $\left.\mathrm{Tf}_{2} \mathrm{~N}\right]-30$ which $\mathrm{CO}_{2}$ sorption capacity is similar to sample A. $\mathrm{CO}_{2}$ sorption capacity of sample A-mbmim[Tf $\left.{ }_{2} \mathrm{~N}\right]-30$ may be related to the type III isotherm (Fig. 4) presented by this sample ${ }^{64}$. Chen et al. ${ }^{52}$ also observed similar behavior to that obtained for sample A-mbmim[Tf $\left.{ }_{2} \mathrm{~N}\right]-30$ when immobilizing PEI (polyethylenimine) in mesoporous alumina. IL immobilization increased $\mathrm{CO}_{2}$ efficiency removal in relation to $\mathrm{N}_{2}$, when compared to pure supports. This behavior is attributed to higher IL/CO affinity than support $/ \mathrm{CO}_{2}^{2,65}$. Selectivity is directly influenced by immobilized IL content. For support S, increasing IL content continuously increased selectivity. For sample A this tendency was observed until IL content of $20 \%$. For $30 \%$ a selectivity reduction was observed probably due to the non-porous behavior (Fig. 4) and also to the fact

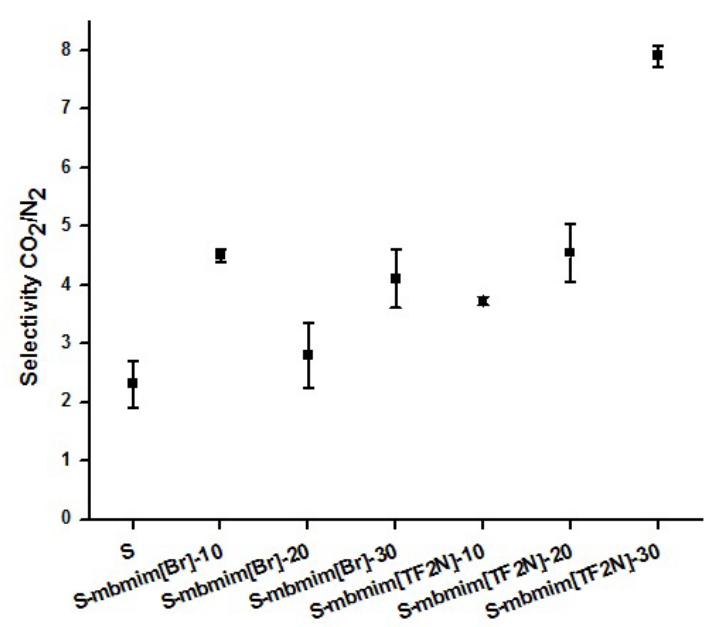

Figure 6. Selectivity at $2.3 \mathrm{MPa}$ of pressure and $45^{\circ} \mathrm{C}$ of temperature.

Table 3. $\mathrm{CO}_{2}$ sorption capacity and $\mathrm{CO}_{2} / \mathrm{N}_{2}$ selectivity for samples $\mathrm{S}$ and $\mathrm{A}$ with and without IL immobilization.

\begin{tabular}{lcc}
\hline Sample & $\begin{array}{c}\text { Sorption Capacity } \\
\left(\mathrm{mg} \mathrm{CO}_{2} / \mathrm{g}\right)\end{array}$ & $\begin{array}{c}\text { Selectivity } \\
\left(\mathrm{CO}_{2} / \mathrm{N}_{2}\right)\end{array}$ \\
\hline A & $61.1( \pm 1.2)$ & $6.1( \pm 0.1)$ \\
A-mbmim[Tf $\mathrm{N}]-10$ & $52.1( \pm 1.0)$ & $6.9( \pm 1.2)$ \\
A-mbmim[Tf $\mathrm{N}]-20$ & $42.7( \pm 2.3)$ & $9.5( \pm 1.0)$ \\
A-mbmim[Tf $\mathrm{N}]-30$ & $57.5( \pm 2.8)$ & $4.8( \pm 0.1)$ \\
S & $81.7( \pm 2.2)$ & $2.31( \pm 0.4)$ \\
S-mbmim[Tf $\mathrm{N}]-10$ & $56.0( \pm 0.7)$ & $3.7( \pm 0.1)$ \\
S-mbmim[Tf $\mathrm{N}]-20$ & $55.8( \pm 1.0)$ & $4.6( \pm 0.5)$ \\
S-mbmim[Tf $\mathrm{N}]-30$ & $45.2( \pm 2.3)$ & $7.9( \pm 0.2)$ \\
\hline
\end{tabular}

that the IL reduces $\mathrm{CO}_{2}$ /support metal interaction. Sample A-mbmim $\left[\mathrm{Tf}_{2} \mathrm{~N}\right]-20$ was more selective and choosen to perform kinetic and recycle tests.

\subsection{Kinetics tests}

Fig. 7 presents kinetic behavior of immobilized sample A-mbmim $\left[\mathrm{Tf}_{2} \mathrm{~N}\right]-20$ compared to kinetic behavior of pure IL mbmim [Tf $\left.{ }_{2} \mathrm{~N}\right]$. It is interesting to note that immobilized ionic liquid presents $\mathrm{CO}_{2}$ sorption $\left(42.7( \pm 2.3) \mathrm{mg} \mathrm{CO}_{2} / \mathrm{g}\right)$ capacity higher than pure IL $\left(14.6( \pm 0.5) \mathrm{mg} \mathrm{CO}_{2} / \mathrm{g}\right)$. In addition, kinetics improves dramatically with immobilization. Pure IL is extremely viscous, needing longer times for $\mathrm{CO}_{2}$ uptake (350 $\mathrm{min})$. In contrast, IL immobilization in solid supports improves mass transfer, resulting in a faster $\mathrm{CO}_{2}$ sorption process $(10 \mathrm{~min})^{27,66-68}$. 


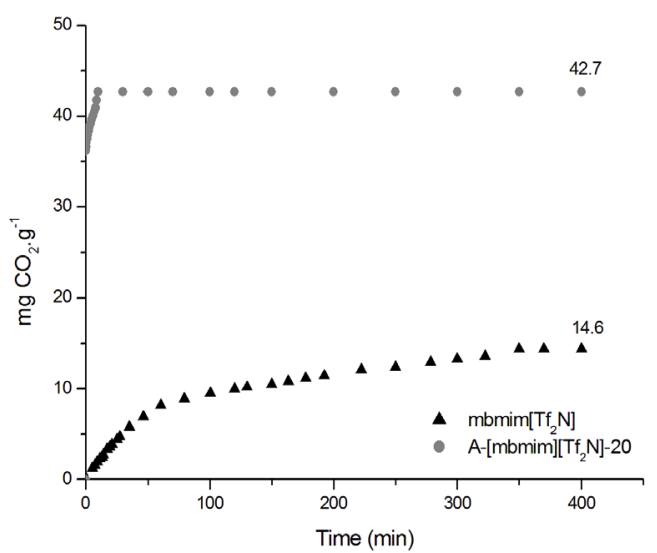

Figure 7. Time course of $\mathrm{CO}_{2}$ uptake in neat: $(\boldsymbol{\Delta}) \operatorname{mbmim}\left[\mathrm{Tf}_{2} \mathrm{~N}\right]$; (•) A-mbmim $\left[\mathrm{Tf}_{2} \mathrm{~N}\right]-20$.

\subsection{Recycle tests}

Fig. 8 shows sorption/desorption tests aiming sample A-mbmim[ $\left.\mathrm{Tf}_{2} \mathrm{~N}\right]-20$ stability evaluation. After 5 sorption/ desorption cycles, $\mathrm{CO}_{2}$ sorption in A-mbmim $\left[\mathrm{Tf}_{2} \mathrm{~N}\right]-20$ was reversible confirming sample stability and reuse.

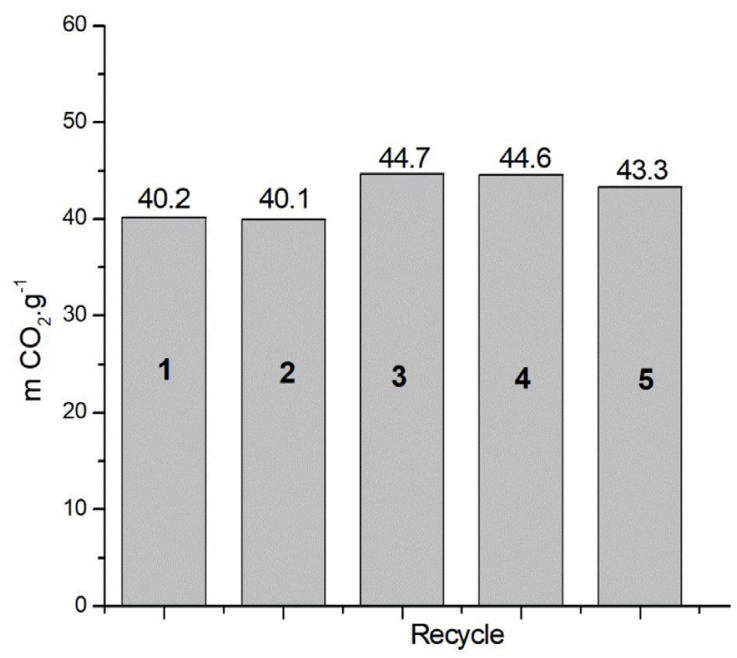

Figure 8. Recycle test: five sorption/desorption cycles applied to the sample A-mbmim[Tf $2 \mathrm{~N}]-20$.

\section{Conclusions}

Imidazolium based IL with different anions were immobilized by wet point method in two different supports. $\mathrm{CO}_{2}$ sorption capacity and $\mathrm{CO}_{2} / \mathrm{N}_{2}$ selectivity were evaluated. When analyzing anion influence we observed that anion $\left[\mathrm{Tf}_{2} \mathrm{~N}\right]^{-}$presented superior performance in relation to $\mathrm{CO}_{2}$ selectivity when compared to $[\mathrm{Br}]$ anion, possibly due to the higher $\mathrm{CO}_{2}$ affinity of fluorinated anions. When comparing supports (alumina and silica), commercial alumina seems to be a good material for this purpose since it combined textural properties (specific surface area, volume and pore radius) with selectivity due to metal presence on its surface. This combination favored its performance in $\mathrm{CO}_{2} / \mathrm{N}_{2}$ selectivity when the concentration of immobilized IL was $20 \%$. The best combination of support and ionic liquid content was obtained with sample A-mbmim[ $\left[\mathrm{Tf}_{2} \mathrm{~N}\right]-20$.

\section{Acknowledgment}

Authors would like to thank PETROBRAS for its financial support. Sandra Einloft thanks CNPq for research grant. This study was financed in part by the Coordenação de Aperfeiçoamento de Pessoal de Nível Superior - Brasil (CAPES) - Finance Code 001.

\section{References}

1. Mohamedali M, Nath D, Ibrahim H, Henni A. Review of Recent Developments in $\mathrm{CO}_{2}$ Capture Using Solid Materials: Metal Organic Frameworks (MOFs). In: Moya BL, Pous J, editors. Greenhouse Gases. London: IntechOpen; 2016. p. 115-154. Available from: http://www.intechopen.com/books/ greenhouse-gases/review-of-recent-developments-in-co2capture-using-solid-materials-metal-organic-frameworks-mofs-

2. Duczinski R, Bernard F, Rojas M, Duarte E, Chaban V, Vecchia FD, et al. Waste derived MCMRH- supported IL for $\mathrm{CO}_{2} / \mathrm{CH}_{4}$ separation. Journal of Natural Gas Science and Engineering. 2018;54:54-64. Available from: http://linkinghub.elsevier.com/ retrieve/pii/S1875510018301446

3. Yuan Z, Eden MR. Toward the Development and Deployment of Large-Scale Carbon Dioxide Capture and Conversion Processes. Industrial and Engineering Chemistry Research. 2016;55(12):3383-419.

4. Kadam R, Panwar NL. Recent advancement in biogas enrichment and its applications. Renewable and Sustainable Energy Reviews. 2017;73:892-903. Available from: http://dx.doi.org/10.1016/j. rser.2017.01.167

5. Wang Y, Zhao L, Otto A, Robinius M, Stolten D. A Review of Post-combustion $\mathrm{CO}_{2}$ Capture Technologies from Coal-fired Power Plants. Energy Procedia. 2017;114:650-65. Available from: http://dx.doi.org/10.1016/j.egypro.2017.03.1209

6. Koytsoumpa EI, Bergins C, Kakaras E. The $\mathrm{CO}_{2}$ economy: Review of $\mathrm{CO}_{2}$ capture and reuse technologies. Journal of Supercritical Fluids. 2018;132:3-16.

7. Guido G, Compagnoni M, Pellegrini LA, Rossetti I. Mature versus emerging technologies for $\mathrm{CO}_{2}$ capture in power plants: Key open issues in post-combustion amine scrubbing and in chemical looping combustion. Frontiers of Chemical Science and Engineering. 2018;12(2):315-25.

8. Leung DYC, Caramanna G, Maroto-Valer MM. An overview of current status of carbon dioxide capture and storage technologies. Renewable and Sustainable Energy Reviews. 2014;39:426-43. Available from: http://dx.doi.org/10.1016/j.rser.2014.07.093 
9. Kang G, Chan ZP, Saleh SBM, Cao Y. Removal of high concentration $\mathrm{CO}_{2}$ from natural gas using high pressure membrane contactors. International Journal of Greenhouse Gas Control. 2017;60:1-9. Available from: http://dx.doi. org/10.1016/j.ijggc.2017.03.003

10. Song C, Liu Q, Ji N, Deng S, Zhao J, Kitamura Y. Natural gas purification by heat pump assisted MEA absorption process. Applied Energy. 2017;204:353-61.

11. Kothandaraman A, Nord L, Bolland O, Herzog HJ, McRae GJ. Comparison of solvents for post-combustion capture of $\mathrm{CO}_{2}$ by chemical absorption. Energy Procedia. 2009;1(1):1373-80. Available from: http://dx.doi.org/10.1016/j.egypro.2009.01.180

12. Thouchprasitchai N, Pintuyothin N, Pongstabodee S. Optimization of $\mathrm{CO}_{2}$ adsorption capacity and cyclical adsorption / desorption on tetraethylenepentamine-supported surface-modified hydrotalcite. Journal of Environmental Sciences. 2017;65:293-305. Available from: http://dx.doi.org/10.1016/j.jes.2017.02.015

13. Ünveren EE, Monkul BÖ, Sarıŏlan Ş, Karademir N, Alper E. Solid amine sorbents for $\mathrm{CO}_{2}$ capture by chemical adsorption: A review. Petroleum. 2016;3(1):37-50

14. Wilkes JS. A Short History of Ionic Liquids - From Molten Salts to Neoteric Solvents. Green Chem. 2002;4(2):73-80.

15. Figueroa JD, Fout T, Plasynski S, Mcllvried H, Srivastava RD. Advances in $\mathrm{CO}_{2}$ capture technology-The U.S. Department of Energy's Carbon Sequestration Program. International Journal of Greenhouse Gas Control. 2008;2(1):9-20.

16. Anthony JL, Anderson JL, Maginn EJ, Brennecke JF. Anion Effects on Gas Solubility in Ionic Liquids. The Journal of Physical Chemistry B. 2005;109(13):6366-74.

17. Lei Z, Dai C, Chen B. Gas solubility in ionic liquids. Chemical Reviews. 2014;114(2):1289-326. Available from: http://www. ncbi.nlm.nih.gov/pubmed/24195614

18. Ramdin M, Amplianitis A, Bazhenov S, Volkov A, Volkov V, Vlugt $\mathrm{TJH}$, et al. Solubility of $\mathrm{CO}_{2}$ and $\mathrm{CH}_{4}$ in ionic liquids: Ideal $\mathrm{CO}_{2} / \mathrm{CH}_{4}$ selectivity. Industrial and Engineering Chemistry Research. 2014;53(40):15427-35.

19. Brennecke JF, Gurkan BE. Ionic liquids for $\mathrm{CO}_{2}$ capture and emission reduction. Journal of Physical Chemistry Letters. 2010;1(24):3459-64.

20. Paolone A, Palumbo O, Trequattrini F, Appetecchi GB. Relaxational Dynamics in the PYR14-IM14 Ionic Liquid by Mechanical Spectroscopy. Materials Research. 2018; 21. Available from: http://dx.doi.org/10.1590/1980-5373-MR-2017-0870.

21. Sarmad S, Mikkola JP, Ji X. Carbon Dioxide Capture with Ionic Liquids and Deep Eutectic Solvents: A New Generation of Sorbents. ChemSusChem. 2017;10(2):324-52.

22. Karimi B, Tavakolian M, Akbari M, Mansouri F. Ionic Liquids in Asymmetric Synthesis: An Overall View from Reaction Media to Supported Ionic Liquid Catalysis. ChemCatChem. 2018;10(15):3173-205.

23. Corvo MC, Sardinha J, Casimiro T, Marin G, Seferin M, Einloft $\mathrm{S}$, et al. A rational approach to $\mathrm{CO}_{2}$ capture by imidazolium ionic liquids: Tuning $\mathrm{CO}_{2}$ solubility by cation alkyl branching. ChemSusChem. 2015;8(11):1935-46.
24. Anthony JL, Anderson JL, Maginn EJ, Brennecke JF. Anion Effects on Gas Solubility in Ionic Liquids. Journal of Physical Chemistry B. 2005;109(13):6366-74. Available from: http:// pubs.acs.org/doi/abs/10.1021/jp0464041

25. Aki SNVK, Mellein BR, Saurer EM, Brennecke JF. High-pressure phase behavior of carbon dioxide with imidazolium-based ionic liquids. Journal of Physical Chemistry B. 2004;108(52):2035520365.

26. Aquino AS, Bernard FL, Borges JV, Mafra L, Vecchia FD, Vieira $\mathrm{MO}$, et al. Rationalizing the role of the anion in $\mathrm{CO}_{2}$ capture and conversion using imidazolium-based ionic liquid modified mesoporous silica. RSC Advances Royal Society of Chemistry. 2015;5(79):64220-7.

27. Safiah MN, Azmi BM, Normawati MY. $\mathrm{CO}_{2}$ Capture Using Silica and Molecular Sieve Impregnated with [hmim] $\left[\mathrm{Tf}_{2} \mathrm{~N}\right]$. International Journal of Chemical Engineering and Applications. 2014;5(4):342-6. Available from: http://www.ijcea.org/index. php $\mathrm{m}=$ content $\& \mathrm{c}=$ index $\& \mathrm{a}=$ show $\&$ catid $=57 \& \mathrm{id}=740$

28. Lemus J, Silva FA, Palomar J, Carvalho PJ, Coutinho JAP. Solubility of carbon dioxide in encapsulated ionic liquids. Separation and Purification Technology. 2018;196:41-6. Available from: https://doi.org/10.1016/j.seppur.2017.08.032

29. Guillet-Nicolas R, Bérubé F, Thommes M, Janicke MT, Kleitz F. Selectively tuned pore condensation and hysteresis behavior in mesoporous SBA-15 silica: Correlating material synthesis to advanced gas adsorption analysis. Journal of Physical Chemistry: C. 2017;121(44):24505-26.

30. Lashaki MJ, Ziaei-Azad H, Sayari A. Insights into the Hydrothermal Stability of Triamine-Functionalized SBA-15 Silica for $\mathrm{CO}_{2}$ Adsorption. ChemSusChem. 2017;10(20):4037-45.

31. Xu X, Song C, Andresen JM, Miller BG, Scaroni AW. Preparation and characterization of novel $\mathrm{CO}_{2}$ "molecular basket" adsorbents based on polymer-modified mesoporous molecular sieve MCM41. Microporous Mesoporous Materials. 2003;62(1-2):29-45.

32. Sánchez Fuentes CE, Guzmán-Lucero D, Torres-Rodriguez M, Likhanova NV, Bolaños JN, Olivares-Xometl O, et al. $\mathrm{CO}_{2} /$ $\mathrm{N}_{2}$ separation using alumina supported membranes based on new functionalized ionic liquids. Separation and Purification Technology. 2017;182:59-68.

33. Magalhaes GC, Ribeiro JON, Vasconcelos DCL, Vasconcelos WL. Production of Pure Granules of Sba-15 Mesoporous Silica. Materials Research. 2018;21(6):e20180148.

34. Nanda S, Reddy SN, Mitra SK, Kozinski JA. The progressive routes for carbon capture and sequestration. Energy Science Engineering. 2016;4(2):99-122.

35. Ben-Mansour R, Habib MA, Bamidele OE, Basha M, Qasem NAA, Peedikakkal A, et al. Carbon capture by physical adsorption: Materials, experimental investigations and numerical modeling and simulations - A review. Applied Energy. 2016;161:225-55. Available from: http://dx.doi.org/10.1016/j.apenergy.2015.10.011

36. Andresova A, Storch J, Traïkia M, Wagner Z, Bendova M, Husson P. Branched and cyclic alkyl groups in imidazoliumbased ionic liquids: Molecular organization and physico-chemical properties. Fluid Phase Equilibria. 2014;371:41-9. Available from: http://dx.doi.org/10.1016/j.fluid.2014.03.004 
37. Haber J, Block JH, Delmon B. Manual of methods and procedures for catalyst characterization (Technical Report). Pure and Applied Chemistry. 1995;67(8-9):1257-306. Available from: https://www.degruyter.com/view/j/pac.1995.67.issue-8-9/ pac199567081257/pac199567081257.xml

38. Koros WJ, Paul DR. Design considerations for measurement of gas sorption in polymers by pressure decay. Journal of Polymer Science: Polymer Physics Edition. 1976;14(10):1903-7. Available from: http://doi.wiley.com/10.1002/pol.1976.180141014

39. Bernard FL, Polesso BB, Cobalchini FW, Chaban VV, Nascimento JF, Vecchia FD, et al. Hybrid Alkoxysilane-Functionalized Urethane-Imide-Based Poly(ionic liquids) as a New Platform for Carbon Dioxide Capture. Energy and Fuels. 2017;31(9):9840-9.

40. Jacquemin J, Gomes MFC, Husson P, Majer V. Solubility of carbon dioxide, ethane, methane, oxygen, nitrogen, hydrogen, argon, and carbon monoxide in 1-butyl-3-methylimidazolium tetrafluoroborate between temperatures $283 \mathrm{~K}$ and $343 \mathrm{~K}$ and at pressures close to atmospheric. Journal of Chemical Thermodynamics. 2006;38(4):490-502.

41. Azimi A, Mirzaei M. Experimental evaluation and thermodynamic modeling of hydrate selectivity in separation of $\mathrm{CO}_{2}$ and $\mathrm{CH}_{4}$. Chemical Engineering Research and Design. 2016;111:262-8. Available from: http://dx.doi.org/10.1016/j.cherd.2016.05.005

42. Tokudome Y, Nakanishi K, Kanamori K, Fujita K, Akamatsu H, Hanada T. Structural characterization of hierarchically porous alumina aerogel and xerogel monoliths. Journal of Colloid and Interface Science. 2009;338(2):506-13.

43. Tettenhorst TR, Hofmann DA. Crystal Chemistry of Boehmite. Clays and Clay Minerals. 1980;28(5):373-80.

44. Bakar RA, Yahya R, Gan SN. Production of High Purity Amorphous Silica from Rice Husk. Procedia Chemistry. 2016;19:189-95. Available from: http://linkinghub.elsevier. com/retrieve/pii/S1876619616001388

45. Zhang X, Guo W, Wu Y, Gong L, Li W, Li X, et al. Cationic polymerization of $\mathrm{p}$-methylstyrene in selected ionic liquids and polymerization mechanism. Polymer Chemistry. 2016;7(32):50995112. Available from: http://dx.doi.org/10.1039/c6py00796a

46. Cha S, Ao M, Sung W, Moon B, Ahlström B, Johansson P, et al. Structures of ionic liquid-water mixtures investigated by IR and NMR spectroscopy. Physical Chemistry Chemical Physics. 2014;16(20):9591-601.

47. Trombetta M, Busca G, Willey RJ. Characterization of silicacontaining aluminum hydroxide and oxide aerogels. Journal of Colloid and Interface Science. 1997;190(2):416-26.

48. Musić S, Dragčević D, Popović S. Hydrothermal crystallization of boehmite from freshly precipitated aluminum hydroxide. Materials Letters. 1999;40(6):269-74.

49. Balsamo M, Erto A, Lancia A, Totarella G, Montagnaro F, Turco R. Post-combustion $\mathrm{CO}_{2}$ capture: On the potentiality of amino acid ionic liquid as modifying agent of mesoporous solids. Fuel. 2018;218:155-61. Available from: https://doi. org/10.1016/j.fuel.2018.01.038

50. Ji X, Tang S, Gu L, Liu T, Zhang X. Synthesis of rod-like mesoporous $\gamma-\mathrm{Al}_{2} \mathrm{O}_{3}$ by an ionic liquid-assisted sol-gel method.
Materials Letters. 2015;151:20-3. Available from: http://dx.doi. org/10.1016/j.matlet.2015.03.022

51. Thommes M, Kaneko K, Neimark AV, Olivier JP, RodriguezReinoso F, Rouquerol J, et al. Physisorption of gases, with special reference to the evaluation of surface area and pore size distribution (IUPAC Technical Report). Pure and Applied Chemistry. 2015;87(9):1051-69.

52. Chen $\mathrm{C}$, Ahn WS. $\mathrm{CO}_{2}$ capture using mesoporous alumina prepared by a sol-gel process. Chemical Engineering Journal. 2011;166(2):646-51. Available from: http://dx.doi.org/10.1016/j. cej.2010.11.038

53. Žilková N, Zukal A, Čejka J. Synthesis of organized mesoporous alumina templated with ionic liquids. Microporous and Mesoporous Materials. 2006;95(1-3):176-9.

54. Kakaire J, Makokha GL, Mwanjalolo M, Mensah AK, Emmanuel M. Effects of Mulching on Soil Hydro-Physical Properties in Kibaale Sub-catchment, South Central Uganda. Applied Ecology and Environmental Sciences. 2015;3(5):127-135.

55. Rimola A, Costa D, Sodupe M, Lambert JF, Ugliengo P. Silica surface features and their role in the adsorption of biomolecules: Computational modeling and experiments. Chemical Reviews. 2013;113(6):4216-313

56. Kim HJ, Yang HC, Chung DY, Yang IH, Choi YJ, Moon JK. Functionalized Mesoporous Silica Membranes for $\mathrm{CO}_{2}$ Separation Applications. Journal of Chemistry. 2015;1-9.

57. Sanz R, Calleja G, Arencibia A, Sanz-Pérez ES. $\mathrm{CO}_{2}$ capture with pore-expanded MCM-41 silica modified with amino groups by double functionalization. Microporous and Mesoporous Materials. 2015;209:165-71.

58. Hojniak SD, Silverwood IP, Khan AL, Vankelecom IFJ, Dehaen W, Kazarian SG, et al. Highly selective separation of carbon dioxide from nitrogen and methane by nitrile/glycol-difunctionalized ionic liquids in supported ionic liquid membranes (SILMs). Journal of Physical Chemistry: B. 2014;118(26):7440-9.

59. Salehi S, Anbia M. High $\mathrm{CO}_{2}$ Adsorption Capacity and $\mathrm{CO}_{2} /$ $\mathrm{CH}_{4}$ Selectivity by Nanocomposites of MOF-199. Energy \& Fuels. 2017;31(5):5376-84. Available from: http://pubs.acs. org/doi/abs/10.1021/acs.energyfuels.6b03347

60. Zhu J, He B, Huang J, Li C, Ren T. Effect of immobilization methods and the pore structure on $\mathrm{CO}_{2}$ separation performance in silica-supported ionic liquids. Microporous and Mesoporous Materials. 2018;260:190-200. Available from: https://doi. org/10.1016/j.micromeso.2017.10.035

61. Anthony JL, Maginn EJ, Brennecke JF. Solubilities and thermodynamic properties of gases in the ionic liquid 1-n-butyl3-methylimidazolium hexafluorophosphate. Journal of Physical Chemistry: B. 2002;106(29):7315-20.

62. Cabello CP, Rumori P, Palomino GT. Carbon dioxide adsorption on MIL-100(M) $(\mathrm{M}=\mathrm{Cr}, \mathrm{V}, \mathrm{Sc})$ metal-organic frameworks: IR spectroscopic and thermodynamic studies. Microporous and Mesoporous Materials. 2014;190:234-9. Available from: http://dx.doi.org/10.1016/j.micromeso.2014.02.015

63. Campbell S, Bernard FL, Rodrigues DM, Rojas MF, Carreño LA, Chaban VV, et al. Performance of metal-functionalized 
rice husk cellulose for $\mathrm{CO}_{2}$ sorption and $\mathrm{CO}_{2} / \mathrm{N}_{2}$ separation. Fuel. 2019;239:737-46.

64. Sing KSW, Everett DH, Haul RAW, Moscou L, Pierotti RA, Rouquérol J, et al. Reporting Physisorption Data For Gas / Solid Systems with Special Reference to the Determination of S. Pure and Applied Chemistry. 1985;57(4):603-19.

65. Arellano IH, Madani SH, Huang J, Pendleton P. Carbon dioxide adsorption by zinc-functionalized ionic liquid impregnated into bio-templated mesoporous silica beads. Chemical Engineering Journal. 2016;283:692-702. Available from: http://dx.doi. org/10.1016/j.cej.2015.08.006

66. Aboudi J, Vafaeezadeh M. Efficient and reversible $\mathrm{CO}_{2}$ capture by amine functionalized-silica gel confined task-specific ionic liquid system. Journal of Advanced Research . 2015;6(4):571-7. Available from: http://dx.doi.org/10.1016/j.jare.2014.02.001

67. Vilarrasa-Garcia E, Moya EMO, Cecilia JA, Cavalcante Junior CL, Jiménez-Jiménez J, Azevedo DCS, et al. $\mathrm{CO}_{2}$ adsorption on amine modified mesoporous silicas: Effect of the progressive disorder of the honeycomb arrangement. Microporous and Mesoporous Materials. 2015;209:172-83. Available from: http://dx.doi.org/10.1016/j.micromeso.2014.08.032

68. Yang N, Wang R. Molecular sieve supported ionic liquids as efficient adsorbent for $\mathrm{CO}_{2}$ capture. Journal of the Serbian Chemical Society. 2015;80(2):265-75. 